\title{
Flavobacterium gelidilacus sp. nov., isolated from microbial mats in Antarctic lakes
}

\author{
Stefanie Van Trappen, Joris Mergaert and Jean Swings \\ Laboratorium voor Microbiologie, Vakgroep Biochemie, Fysiologie en Microbiologie, Universiteit \\ Gent, K. L. Ledeganckstraat 35, B-9000 Gent, Belgium
}

Correspondence

Stefanie Van Trappen

stefanie.vantrappen@UGent.be

\begin{abstract}
Twenty-two isolates from microbial mats in eastern Antarctic lakes showed similar fatty acid compositions and were investigated further using a polyphasic taxonomic approach. Repetitive extragenic palindromic DNA-PCR fingerprinting of the 22 strains revealed three groups, and DNA-DNA hybridizations between representatives showed more than $87 \%$ DNA-DNA reassociation with each other. 16S rRNA gene sequence analysis placed two representative strains, LMG $21477^{\top}$ and LMG 21619 , within the genus Flavobacterium, with $95 \cdot 1 \%$ sequence similarity to Flavobacterium flevense, $95.0 \%$ to Flavobacterium tegetincola, less than $95 \%$ to other Flavobacterium species and less than $90 \%$ to representatives of other genera. The name Flavobacterium gelidilacus sp. nov. is proposed, with LMG $21477^{\top}$ (=DSM $15343^{\top}$ ) as the type strain, and a description of the species is given on the basis of morphological, biochemical and physiological characteristics and fatty acid composition. The $\mathrm{G}+\mathrm{C}$ content of the genomic DNA is 30-0-30.4 mol\%.
\end{abstract}

Members of the genus Flavobacterium have been isolated from diverse habitats such as fresh water (Flavobacterium aquatile, Flavobacterium flevense, Flavobacterium hibernum, Flavobacterium saccharophilum), soil (Flavobacterium johnsoniae, Flavobacterium pectinovorum, Flavobacterium xanthum) and sea ice (Flavobacterium gillisiae); some are known as important fish pathogens (Flavobacterium branchiophilum, Flavobacterium columnare, Flavobacterium psychrophilum). They are abundant in freshwater and marine ecosystems, and these heterotrophic bacteria may have a specialized role in the uptake and degradation of the highmolecular-mass fraction of dissolved organic matter in these environments (Kirchman, 2002).

Several novel species, added to the genus since 1996, were derived from Antarctic habitats, and several new genera containing polar organisms have recently been described within the family Flavobacteriaceae (Gelidibacter, Psychroserpens, Polaribacter, Psychroflexus, Salegentibacter). So far, only one species, Flavobacterium tegetincola, has been isolated from a cyanobacterial mat, collected from the Antarctic saline Ace Lake, located in the Vestfold Hills (McCammon \& Bowman, 2000).

Published online ahead of print on 24 January 2003 as DOI 10.1099/ ijs.0.02583-0.

Abbreviation: rep-PCR, repetitive extragenic palindromic DNA-PCR.

The GenBank/EMBL/DDBJ accession numbers for the 16S rRNA gene sequences of strains LMG 21619 and LMG $21477^{\top}$ are AJ507151 and AJ440996.
During the MICROMAT project (November 1998 to February 2001), 746 bacterial strains were isolated under heterotrophic conditions from microbial mat samples, collected from 10 Antarctic lakes in the Vestfold Hills (lakes Ace, Druzhby, Grace, Highway, Pendant, Organic and Watts), the Larsemann Hills (Lake Reid) and the McMurdo Dry Valleys (lakes Hoare and Fryxell) (Van Trappen et al., 2002). Numerical analysis of their fatty acid composition revealed 41 clusters, and 16S rRNA gene sequence analysis, performed on representative strains, showed that they belong to the $\alpha$-, $\beta$ - and $\gamma$-subclasses of the Proteobacteria, the high- and low-G $+\mathrm{C}$-content Gram-positives and to the Cytophaga-Flavobacterium-Bacteroides branch (Van Trappen et al., 2002). The results of fatty acid analysis and 16S rRNA gene sequence analysis showed that the diversity of heterotrophic bacteria in microbial mats from Antarctic lakes is very high. Moreover, many fatty acid clusters contain multiple taxa, as defined by repetitive extragenic palindromic DNA-PCR (rep-PCR) fingerprinting, a technique used to investigate the genomic diversity of each fatty acid cluster in more detail (Van Trappen et al., 2001).

In the present work, we studied further the taxonomic relationships of 22 strains from fatty acid cluster 10 (as delineated by Van Trappen et al., 2002), related to the genus Flavobacterium, by genomic and phenotypic characterization. Van Trappen et al. (2002) found less than 96\% 16S rRNA gene sequence similarity to the closest relatives within the genus Flavobacterium, indicating that these strains constitute a novel species (Stackebrandt \& Goebel, 1994). 
Table 1. Strains investigated in this study

Numbers with an 'R-' prefix refer to strains from the research collection of the LMG, as used by Van Trappen et al. (2002).

\begin{tabular}{|ll|}
\hline Strain & \multicolumn{1}{c|}{ Isolation source } \\
\hline Rep-PCR profile type I & Ace Lake, Vestfold Hills \\
LMG $21477^{\mathrm{T}}\left(=\mathrm{DSM} 15343^{\mathrm{T}}=\mathrm{R}-8899^{\mathrm{T}}\right)$, R-8897, R-8908, R-8969, R-8972, R-9283 & Lake Watts, Vestfold Hills \\
R-9024 & Pendant Lake, Vestfold Hills \\
R-11278 & Lake Reid, Larsemann Hills \\
LMG $21618(=\mathrm{R}-12566)$ & \\
Rep-PCR profile type II & Ace Lake, Vestfold Hills \\
LMG $21619(=\mathrm{R}-8885)$, R-8888, R-8898, R-9104, R-9110, R-9158 \\
LMG 21621 (=R-9330), R-9004, R-9019 & Lake Watts, Vestfold Hills \\
R-11078, R-11277, R-8983 & Pendant Lake, Vestfold Hills \\
Rep-PCR profile type III & \\
LMG 21620 (=R-9056) & Pendant Lake, Vestfold Hills \\
\hline
\end{tabular}

The isolates investigated, together with their sources, are listed in Table 1 . The strains were routinely cultivated on $\mathrm{R} 2 \mathrm{~A}$ medium (Difco) at $20^{\circ} \mathrm{C}$ for $48 \mathrm{~h}$ or, for strain LMG $8328^{\mathrm{T}}$, on TSA medium (BBL) at $20^{\circ} \mathrm{C}$ for $48 \mathrm{~h}$, except where mentioned otherwise.

DNA was prepared according to the method of Pitcher et al. (1989), and rep-PCR fingerprinting was performed on all strains of fatty acid analysis cluster 10 of Van Trappen et al. (2002), using the primer $\mathrm{GTG}_{5}$ (Versalovic et al., 1991), as described by Rademaker \& de Bruijn (1997) and Rademaker et al. (2000). The 22 strains listed in Table 1 showed similar profiles (data not shown). Numerical analysis (data not shown) was carried out using the BIONUMERICS software package (Applied Maths), as described by the same authors, and these 22 strains could be divided into three clusters according to their profile type, hereafter referred to as rep-PCR profile type I (with 9 strains), rep-PCR profile type II (with 12 strains) and rep-PCR profile type III (containing the single strain LMG 21620) (Table 1). Versalovic et al. (1994) have shown that strains with the same rep-PCR profile are always closely related, and this has been confirmed by several authors (e.g. Rademaker \& De Bruijn, 1997).

Five strains (LMG $21477^{\mathrm{T}}$, LMG 21618, LMG 21619, LMG 21620 and LMG 21621) representing the three rep-PCR profile types and chosen on the basis of their isolation source were used for DNA-DNA hybridizations to investigate their genomic relatedness. DNA-DNA hybridizations were carried out with photobiotin-labelled probes in microplate wells, as described by Ezaki et al. (1989), using a HTS7000 Bio Assay Reader (Perkin Elmer) for the fluorescence measurements. The hybridization temperature was $30{ }^{\circ} \mathrm{C}$ and reciprocal experiments were performed for every pair of strains. The DNA-DNA binding values among the five strains were high, ranging from 87 to $97 \%$, and differences between reciprocal experiments were less than $13 \%$. These DNA-DNA binding values confirm that the 22 strains belong to a single species (Wayne et al., 1987).
The $\mathrm{G}+\mathrm{C}$ content of the DNAs from strains LMG $21477^{\mathrm{T}}$, LMG 21618, LMG 21619, LMG 21620 and LMG 21621 was determined using an HPLC method. DNA was enzymically degraded into nucleosides as described by Mesbah et al. (1989). The nucleoside mixture obtained was then separated by HPLC using a Waters Symmetry Shield C8 column thermostatted at $37^{\circ} \mathrm{C}$. The solvent was $0.02 \mathrm{M} \mathrm{NH}_{4} \mathrm{H}_{2} \mathrm{PO}_{4}$, pH $4 \cdot 0$, with $1 \cdot 5 \%$ acetonitrile. Non-methylated $\lambda$-phage DNA (Sigma) was used as the calibration reference. The $\mathrm{G}+\mathrm{C}$ contents of the novel strains were $30 \cdot 0-30 \cdot 4 \mathrm{~mol} \%$, which is slightly below the range $(32-37 \mathrm{~mol} \% \mathrm{G}+\mathrm{C}$ ) mentioned by Bernardet et al. (1996) for the genus Flavobacterium.

Almost-complete 16S rRNA gene sequences (1467-1468 bp) of strains LMG $21477^{\mathrm{T}}$ (rep-profile type I) and LMG 21619 (rep-profile type II) were obtained as described previously (Mergaert et al., 2001). The most closely related sequences were found using the FASTA program. Phylogenetic analysis was performed using the BIONUMERICS software package, taking into account homologous nucleotide positions after discarding all unknown bases and gaps. A neighbour-joining dendrogram (Saitou \& Nei, 1987) with the nearest phylogenetic relatives was constructed on the basis of global alignment of the sequences, using the same software package (Fig. 1). Dendrograms obtained using maximum-parsimony and maximum-likelihood analyses showed essentially the same topography. The $16 \mathrm{~S}$ rRNA gene sequences of strains LMG $21477^{\mathrm{T}}$ and LMG 21619 differed by only one base, and showed $95 \cdot 1 \%$ similarity to that of $F$. flevense, $95 \cdot 0 \%$ to that of F. tegetincola, less than $95 \%$ to sequences of other Flavobacterium species and less than $90 \%$ to sequences of other genera, indicating that they belong to a novel Flavobacterium species.

The fatty acid compositions are based on the data generated by Van Trappen et al. (2002), or were determined as described by the same authors. The 22 novel strains yielded very similar fatty acid profiles. The mean composition was $4 \%$ $14: 0$ iso, $10 \% 15: 0,1 \% 15: 03-\mathrm{OH}, 8 \% 15: 0$ anteiso, 


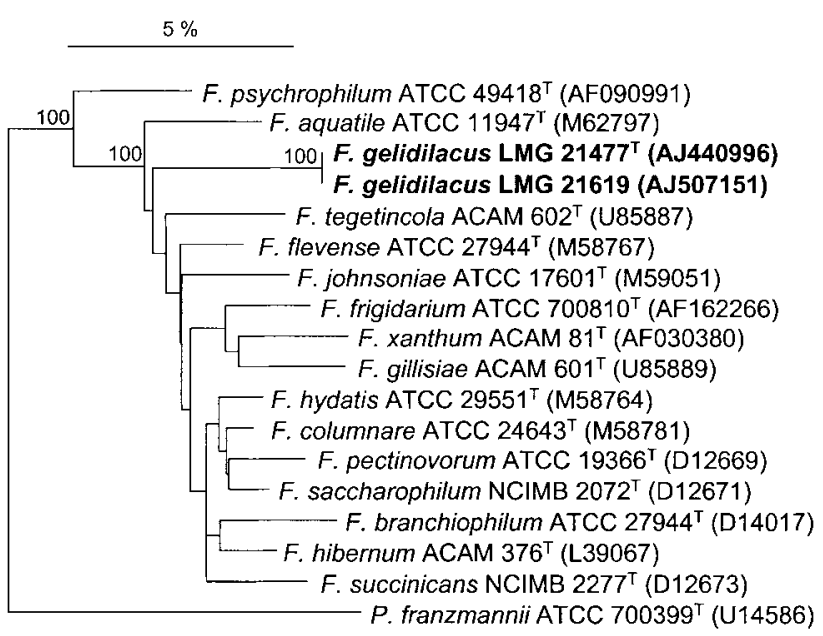

Fig. 1. Neighbour-joining dendrogram based on 16S rDNA sequences showing the estimated phylogenetic relationships of Flavobacterium gelidilacus sp. nov., other Flavobacterium species and Polaribacter franzmannii (outgroup). Bootstrap values are shown as percentages of 1000 replicates, if higher than $95 \%$. Bar, $5 \%$ sequence divergence.

$12 \% 15: 0$ iso, $6 \% 15: 0$ iso $3-\mathrm{OH}, 1 \% 15: 1$ anteiso, $10 \%$ $15: 1$ iso, $6 \% 15: 1 \omega 6 c, 8 \% 16: 0$ iso, $10 \% 16: 0$ iso $3-\mathrm{OH}$, $4 \% 16: 1$ iso, $6 \% 17: 0$ iso $3-\mathrm{OH}, 3 \% 17: 1 \omega 6 c, 2 \% 17: 1$ iso $\omega 9 c, 1 \% 18: 1 \omega 5 c$ and $2 \% 15: 0$ iso $2-\mathrm{OH}$ and/or $16: 1 \omega 6 c$. Other fatty acids each accounted for less than $1 \%$. The fatty acid profiles of the novel strains resemble those determined for other Flavobacterium species (Bernardet et al., 1996), but differ in terms of the relative amounts of $15: 0$ anteiso, 15:0 iso, $16: 0$ iso and 16:0 iso $3-\mathrm{OH}$.

The following morphological, physiological and biochemical tests were performed. Colony morphology was determined on R2A medium after 6 days. In addition, growth and adherence of colonies on marine and nutrient agars, TSA and Anacker \& Ordal's agar (Anacker \& Ordal, 1955) were tested after 14 days growth. Cells were tested for their reaction to the Gram stain and for catalase and oxidase activity. Tests in the commercial systems API ZYM, API 20NE and API 20E (bioMérieux) were performed according to the instructions of the manufacturer. API ZYM tests were read after $4 \mathrm{~h}$ incubation at $20^{\circ} \mathrm{C}$; other API tests were read after $48 \mathrm{~h}$ at $20^{\circ} \mathrm{C}$. Congo red absorption (Bernardet et al., 2002), production of flexirubin-type pigments (Reichenbach, 1989), the presence of gliding motility, degradation of casein and chitin (Reichenbach \& Dworkin, 1981), alginate (West \& Colwell, 1984), DNA (using DNA agar from Difco, supplemented with $0.01 \%$ toluidine blue from Merck), pectin (Paton, 1959), starch and L-tyrosine (Barrow \& Feltham, 1993), the production of a brown diffusible pigment on L-tyrosine agar and the precipitation of egg-yolk agar (Barrow \& Feltham, 1993) were also investigated; reactions were read after 5 days. Hydrolysis of carboxymethylcellulose was tested in Anacker \& Ordal's broth gelified with $3 \%$ carboxymethylcellulose sodium salt (high viscosity; Sigma). This medium was stab-inoculated, and liquefaction of the medium within 7 days was scored as a positive reaction. Growth at different temperatures was assessed after 5 days incubation. Salt tolerance was tested on R2A medium supplemented with $1-10 \% \mathrm{NaCl}$ after 14 days incubation.

The strains showed morphological characteristics typical of Flavobacterium (Bernardet et al., 2002) and were almost identical in their physiological and biochemical characteristics (see Description). The novel species can be clearly differentiated from other Flavobacterium species by means of several phenotypic characteristics (Table 2).

The results of the polyphasic analysis support the recognition of a novel species within the genus Flavobacterium, for which the name Flavobacterium gelidilacus sp. nov. is proposed.

\section{Description of Flavobacterium gelidilacus sp. nov.}

Flavobacterium gelidilacus (ge.li.di.la'cus. L. adj. gelidus ice-cold; L. n. lacus lake; N.L. gen. n. gelidilacus of the ice-cold lake, referring to the isolation source, microbial mats in Antarctic lakes).

Gram-negative rods, $<1 \times 2-4 \mu \mathrm{m}$, that exhibit gliding motility on nutrient-poor medium (R2A), except for strains LMG $21477^{\mathrm{T}}$ and LMG 21619, for which no gliding motility is detected. Strains grow at $5-25^{\circ} \mathrm{C}$, with optimal growth at $20^{\circ} \mathrm{C}$; no growth at $30^{\circ} \mathrm{C}$. Yellow to orange, convex, translucent colonies, $1-4 \mathrm{~mm}$ in diameter and with entire margins, are formed on R2A plates after 6 days at $20{ }^{\circ} \mathrm{C}$. Colonies on Anacker \& Ordal's agar are flat, round with entire margins and $0 \cdot 5-1 \mathrm{~mm}$ in diameter after 14 days incubation. Growth also occurs on TSA, nutrient agar and marine agar, and colonies do not adhere to the agar. Degrades casein and starch. Gelatinase activity is observed, except in the case of strain LMG 21619. Catalase- and oxidase-positive. No growth is observed on glucose, arabinose, mannose, mannitol, $N$-acetylglucosamine, maltose, gluconate, caprate, adipate, malate, citrate or phenylacetate. Acid is not produced from glucose, mannitol, inositol, sorbitol, rhamnose, sucrose, melibiose, amygdalin or arabinose. Agar, alginate, pectin, chitin, aesculin, carboxymethylcellulose, DNA, tyrosine and urea are not degraded. Congo red is not absorbed and no flexirubin-type pigments are present. There is no production of a brown diffusible pigment on L-tyrosine agar and no precipitate is formed on egg-yolk agar. The Voges-Proskauer reaction and tests for indole production, citrate utilization, nitrate reduction and hydrogen sulfide production are negative. None of the strains shows activity for arginine dihydrolase, lysine decarboxylase, ornithine decarboxylase, tryptophan deaminase, lipase $\left(\mathrm{C}_{14}\right), \alpha$-chymotrypsin, $\alpha$-galactosidase, $\beta$-galactosidase, $\beta$-glucuronidase, $\alpha$-mannosidase or $\alpha$-fucosidase. Weak enzymic activity is observed for cystine arylamidase, 
Table 2. Characteristics that differentiate between F. gelidilacus sp. nov. and other Flavobacterium species

Species: 1, F. gelidilacus sp. nov.; 2, F. frigidarium; 3, F. hibernum; 4, F. xanthum; 5, F. gillisiae; 6, F. tegetincola; 7, F. flevense; 8, F. aquatile; 9, F. branchiophilum; 10, F. columnare; 11, F. psychrophilum; 12, F. hydatis; 13, F. johnsoniae; 14, F. pectinovorum; 15, F. saccharophilum; 16, F. succinicans. Data were taken from Bernardet et al. (1996), McCammon et al. (2000), Humphry et al. (2001) and this study. +, Positive; $(+)$, positive, weak or delayed response; -, negative; $\mathrm{V}$, results vary between strains of species or between references; ND, no data available.

\begin{tabular}{|c|c|c|c|c|c|c|c|c|c|c|c|c|c|c|c|c|}
\hline Characteristic & 1 & 2 & 3 & 4 & 5 & 6 & 7 & 8 & 9 & 10 & 11 & 12 & 13 & 14 & 15 & 16 \\
\hline \multicolumn{17}{|l|}{ Growth on: } \\
\hline TSA & + & + & + & + & + & + & + & $(+)$ & - & - & - & + & + & + & + & + \\
\hline Nutrient agar & + & + & + & + & + & + & + & - & - & - & - & + & + & + & + & + \\
\hline Growth at $25^{\circ} \mathrm{C}$ on agar & + & - & + & $(+)$ & $(+)$ & $(+)$ & + & + & + & + & - & + & + & + & + & + \\
\hline Flexirubin-type pigment & - & - & + & - & - & - & - & - & - & + & + & + & + & + & + & - \\
\hline Congo red absorption & - & + & - & - & - & - & - & - & - & + & - & - & $\mathrm{V}$ & - & - & - \\
\hline Glucose utilization & - & + & + & + & + & + & + & $\mathrm{ND}$ & $\mathrm{ND}$ & - & - & + & + & + & + & + \\
\hline Acid from carbohydrates & - & - & + & + & + & + & + & + & + & - & - & + & + & + & + & + \\
\hline \multicolumn{17}{|l|}{ Degradation of: } \\
\hline Casein & + & + & + & + & + & - & - & + & + & + & + & + & + & + & + & + \\
\hline Starch & + & - & + & + & + & - & $\mathrm{ND}$ & $\mathrm{V}$ & + & - & - & + & + & + & + & + \\
\hline Carboxymethylcellulose & - & - & - & - & - & - & - & - & - & - & - & ND & + & + & + & ND \\
\hline Agar & - & - & - & - & - & - & + & - & - & - & - & - & - & - & + & - \\
\hline Alginate & - & - & - & - & - & - & - & $\mathrm{ND}$ & $\mathrm{ND}$ & $\mathrm{ND}$ & - & - & + & + & $\mathrm{ND}$ & $\mathrm{ND}$ \\
\hline Pectin & - & - & - & - & - & - & + & ND & $\mathrm{ND}$ & $\mathrm{ND}$ & - & + & + & + & + & ND \\
\hline Chitin & - & - & - & - & + & - & - & - & - & - & - & $(+)$ & + & + & - & - \\
\hline Aesculin & - & + & + & + & + & - & + & $\mathrm{V}$ & - & - & - & + & + & + & + & + \\
\hline DNA & - & - & + & - & - & - & - & - & - & + & $(+)$ & + & + & + & - & + \\
\hline Tyrosine & - & - & + & - & - & - & - & $\mathrm{V}$ & + & - & $\mathrm{V}$ & + & + & + & + & - \\
\hline Precipitate on egg-yolk agar & - & - & - & - & - & - & - & + & + & + & + & - & - & - & - & - \\
\hline$\beta$-Galactosidase activity & - & - & + & - & - & - & + & ND & + & - & - & + & + & + & + & + \\
\hline $\mathrm{H}_{2} \mathrm{~S}$ production & - & - & - & + & - & - & - & - & - & + & - & - & - & $\mathrm{ND}$ & + & + \\
\hline Nitrate reduction & - & - & + & + & - & - & $\mathrm{ND}$ & ND & - & $\mathrm{ND}$ & - & + & + & + & + & $\mathrm{V}$ \\
\hline Mean $\mathrm{G}+\mathrm{C}$ content $(\mathrm{mol} \%)$ & 30 & 35 & 36 & 36 & 32 & 32 & 35 & 33 & 33 & 32 & 35 & 34 & 34 & 35 & 33 & 36 \\
\hline
\end{tabular}

medium activity is found for acid phosphatase, esterase lipase $\left(\mathrm{C}_{8}\right)$, phosphohydrolase and $\alpha$-glucosidase and strong activity is found for alkaline phosphatase, leucine arylamidase and valine arylamidase. No $\beta$-glucosidase or $N$-acetyl$\beta$-glucosaminidase activity is detected, except for strain LMG 21621. Different reactions are obtained for esterase $\left(\mathrm{C}_{4}\right)$ and trypsin. The cells contain the fatty acids $15: 0$ iso, $16: 0$ iso $3-\mathrm{OH}, 15: 1$ iso, $15: 0,15: 0$ anteiso and $16: 0$ iso as the main constituents. Growth occurs in the absence of $\mathrm{NaCl}$ and in the presence of $1-5 \% \mathrm{NaCl}$, but not $10 \%$ $\mathrm{NaCl}$, indicating that the strains are not halophilic but merely halotolerant. The $\mathrm{G}+\mathrm{C}$ content is $30 \cdot 0-30 \cdot 4 \mathrm{~mol} \%$.

The type strain is LMG $21477^{\mathrm{T}}$ (=DSM $15343^{\mathrm{T}}$ ). Twentytwo strains were isolated from microbial mats from freshwater and saline lakes in eastern Antarctica (Table 1).

\section{Acknowledgements}

This work was funded by the Bijzonder Onderzoeksfonds, Universiteit Gent, Belgium. Part of this work was conducted within the framework of the MICROMAT project 'Biodiversity of microbial mats in Antarctica' (project no. BIO4980040), funded by the European Commission under the Biotech Programme.

\section{References}

Anacker, R. L. \& Ordal, E. J. (1955). Study of a bacteriophage infecting the myxobacterium Chondrococcus columnaris. J Bacteriol 70, 738-741.

Barrow, G. I. \& Feltham, R. K. A. (1993). Cowan and Steel's Manual for the Identification of Medical Bacteria, 3rd edn. Cambridge: Cambridge University Press.

Bernardet, J.-F., Segers, P., Vancanneyt, M., Berthe, F., Kersters, K. \& Vandamme, P. (1996). Cutting a Gordian knot: emended classification and description of the genus Flavobacterium, emended description of the family Flavobacteriaceae, and proposal of Flavobacterium hydatis nom. nov. (basonym, Cytophaga aquatilis Strohl and Tait 1978). Int J Syst Bacteriol 46, 128-148.

Bernardet, J.-F., Nakagawa, Y. \& Holmes, B. (2002). Proposed minimal standards for describing new taxa of the family Flavobacteriaceae and emended description of the family. Int J Syst Evol Microbiol 52, 1049-1070.

Ezaki, T., Hashimoto, Y. \& Yabuuchi, E. (1989). Fluorometric deoxyribonucleic acid-deoxyribonucleic acid hybridization in microdilution wells as an alternative to membrane filter hybridization in which radioisotopes are used to determine genetic relatedness among bacterial strains. Int J Syst Bacteriol 39, 224-229.

Humphry, D. R., George, A., Black, G. W. \& Cummings, S. P. (2001). Flavobacterium frigidarium sp. nov., an aerobic, psychrophilic, xylanolytic and laminarinolytic bacterium from Antarctica. Int J Syst Evol Microbiol 51, 1235-1243. 
Kirchman, D. L. (2002). The ecology of Cytophaga-Flavobacterium in aquatic environments. FEMS Microbiol Ecol 39, 91-100.

McCammon, S. A. \& Bowman, J. P. (2000). Taxonomy of Antarctic Flavobacterium species: description of Flavobacterium gillisiae sp. nov., Flavobacterium tegetincola sp. nov. and Flavobacterium xanthum sp. nov., nom. rev. and reclassification of [Flavobacterium] salegens as Salegentibacter salegens gen. nov., comb. nov. Int J Syst Evol Microbiol 50, 1055-1063.

Mergaert, J., Verhelst, A., Cnockaert, M. C., Tan, T.-L. \& Swings, J. (2001). Characterization of facultative oligotrophic bacteria from polar seas by analysis of their fatty acids and $16 \mathrm{~S}$ rDNA sequences. Syst Appl Microbiol 24, 98-107.

Mesbah, M., Premachandran, U. \& Whitman, W. B. (1989). Precise measurement of the $\mathrm{G}+\mathrm{C}$ content of deoxyribonucleic acid by highperformance liquid chromatography. Int J Syst Bacteriol 39, 159-167.

Paton, A. M. (1959). An improved method for preparing pectate gels. Nature 183, 1812-1813.

Pitcher, D. G., Saunders, N. A. \& Owen, R. J. (1989). Rapid extraction of bacterial genomic DNA with guanidium thiocyanate. Lett Appl Microbiol 8, 151-156.

Rademaker, J. L. W. \& de Bruijn, F. J. (1997). Characterization and classification of microbes by rep-PCR genomic fingerprinting and computer assisted pattern analysis. In DNA Markers: Protocols, Applications and Overviews, pp. 151-171. Edited by G. Caetano-Anollés \& P. M. Gresshoff. New York: Wiley.

Rademaker, J. L. W., Hoste, B., Louws, F. J., Kersters, K., Swings, J., Vauterin, L., Vauterin, P. \& de Bruijn, F. J. (2000). Comparison of AFLP and rep-PCR genomic fingerprinting with DNA-DNA homology studies: Xanthomonas as a model system. Int J Syst Evol Microbiol 50, 665-677.

Reichenbach, H. (1989). Order I. Cytophagales Leadbetter 1974, $99^{\mathrm{AL}}$. In Bergey's Manual of Systematic Bacteriology, vol. 3, pp. 2011-2013. Edited by J. T. Staley, M. P. Bryant, N. Pfennig \& J. G. Holt. Baltimore: Williams \& Wilkins.

Reichenbach, H. \& Dworkin, M. (1981). Introduction to the gliding bacteria. In The Prokaryotes, vol. 1, pp. 315-327. Edited by M. P. Starr, H. Stolp, H. G. Trüper, A. Balows \& H. G. Schlegel. Berlin: Springer.

Saitou, N. \& Nei, M. (1987). The neighbour-joining method: a new method for reconstructing phylogenetic trees. Mol Biol Evol 4, 406-425.

Stackebrandt, E. \& Goebel, B. M. (1994). Taxonomic note: a place for DNA-DNA reassociation and 16S rRNA sequence analysis in the present species definition in bacteriology. Int J Syst Bacteriol 44, 846-849.

Van Trappen, S., Mergaert, J. \& Swings, J. (2001). Genomic diversity of heterotrophic bacteria in microbial mats from Antarctic lakes. In Abstracts of the 8th SCAR International Biology Symposium: Antarctic Biology in a Global Context, Amsterdam. Abstract no. S5O09.

Van Trappen, S., Mergaert, J., Van Eygen, S., Dawyndt, P., Cnockaert, M. C. \& Swings, J. (2002). Diversity of 746 heterotrophic bacteria isolated from microbial mats from ten Antarctic lakes. Syst Appl Microbiol 25, 603-610.

Versalovic, J., Koeuth, T. \& Lupski, J. R. (1991). Distribution of repetitive DNA sequences in eubacteria and application to fingerprinting in bacterial genomes. Nucleic Acids Res 19, 6823-6831.

Versalovic, J., Schneider, M., de Bruijn, F. J. \& Lupski, J. R. (1994). Genomic fingerprinting of bacteria using repetitive sequence-based polymerase chain reaction. Methods Mol Cell Biol 5, 25-40.

Wayne, L. G., Brenner, D. J., Colwell, R. R. \& 9 other authors (1987). International Committee on Systematic Bacteriology. Report of the ad hoc committee on reconciliation of approaches to bacterial systematics. Int J Syst Bacteriol 37, 463-464.

West, P. A. \& Colwell, R. R. (1984). Identification and classification of the Vibrionaceae - an overview. In Vibrios in the Environment, pp. 285-363. Edited by R. R. Colwell. New York: Wiley. 